\title{
Moral Hazard on Public Health Insurance: Evidence from BPJS in Indonesia
}

\author{
Rogatianus Maryatmo, Jeanne Ellyawati
}

\begin{abstract}
In early 2014 State Health Insurance program was launched by Indonesian Government. The program is called Badan Penyelenggara Jaminan Sosial (BPJS). The mission of the BPJS is that in the end of 2019 all Indonesian People are already covered by the State Health Insurance.

This research is aimed to investigate that moral hazard is inevitable from the public health insurance. Using convenience method, 1011 data were collected. There are 893 member of BPJS, and there are 117 were not member of BPJS yet. One is datum missing. Cross-Tabulation and Chi-Square are employed to test the availability of moral hazard.

It is found out that moral hazard is inevitable in the health insurance of BPJS. They are who are already member of BPJS tend to visit doctor frequently than that they are who are not member yet. They are whose premium are paid out of pocket tend to visit doctor more frequently than that they are whose premium is partly or totally paid by other parties.
\end{abstract}

Keywords: health insurance, moral hazard, effect lemon, cherry picking theory, Cross Tabulation, Chi-Squares

\section{INTRODUCTION}

BPJS a state enterprise which provides services for social health insurance in Indonesia was launched on 1 January 2014. BPJS is an abbreviation for Badan Penyelenggara Janinan Sosial Kesehatan. Under Indonesian Government Regulation No. 24 2011, BPJS was designed to provide social insurance program toward universal health care coverage in

Indonesia (https://www.bpjsketenagakerjaan.go.id, 2011) BPJS program is an Indonesian government big step program to improve public health. However as a new program, the implementation of the program faced many problems, which need to be assessed. One important problem was that in 2017, financial deficit of BPJS was 8.7 trillion rupiah. In 2018, the deficit was 16.5 trillion rupiah.

It was claimed that by the end of 2016, 70 percent of Indonesian population or about 174 million people were already covered by BPJS. It was targeted by BPJS that members of BPJS increase up to 201 million members by the end of 2017. By the end of 2019, it was targeted that all Indonesian people or about 257 million people were covered by BPJS (http://www.finance.detik.com, 2017).

By the $1^{\text {st }}$ November 2017 it was reported that the members of health insurance of BPJS recruited were

183.579.083 which were less than that have been targeted. There are three categories of BPJS members. The first is who are fully subsidized by local and central government. There are about 111.593 .654 or 60.8 percent of the whole health insurance BPJS members which are under this

Revised Manuscript Received on July 18, 2019.

Rogatianus Maryatmo, Universitas Atma Jaya Yogyakarta, (r.maryatmo@uajy.ac.id)

Jeanne Ellyawati, Universitas Atma Jaya Yogyakarta (j.ellyawati@uajy.ac.id) category. The term for members of BPJS under the first category is they are whose premium is fully paid by Indonesian government (PBI). The members of BPJS under the category of PBI, the premium are totally subsidized by government.

The second category is members BPJS whose premium of BPJS are partly or fully subsidized by the company where they work.

The third category is members of BPJS whose premium independently paid by them self. The term of member of BPJS under this category is Independent members (PM). There are about 29.006.196 people or about 16 percent of the whole members of health insurance BPJS which are under this category.

Since that the members of BPJS are already $70 \%$ of total population of Indonesia, according to the law of the large number, BPJS should have a good estimate of the fair price of the premium. According to the BPJS report in the end of 2016 BPJS suffered from deficit up to 5 trillion rupiah, or about almost $10 \%$ of the total claim. In this research, it will be studied the causes of the inefficiency of the health insurance.

Moral hazard is one of the most suspected causes of the inefficiency.

\section{THEORETICAL BACKGROUND}

Theoretically, there are tree explanations how health insurance are deficit or inefficient. The theory are asymmetric information, risk-type preference of insured agents which are lemon principle or cherry picking, and moral hazard theory. Asymmetric information is happened when one party has more information than another party. In the case of health insurance, the insured agents have more information about their health than that of insurer agents. The insured agents know better about their health. Since the insured agents have better information about their health than the insurer, for a certain rate of premium, the riskier agents tend to buy the insurance than that of healthier agents (Binger, 1988; Hackman et.al., 2012;. Since the insured agents are dominated by the riskier agents, so it is expected that the insurance holders tend to go to visit doctor more than the uninsured agents. The price of premium tend to be more expensive. The health insurance is inefficient.

Second is theory of risk-type preference on health insurance. The theory are lemon principle and cherry picking. According to lemon principle, they are who high risk tend to buy insurance premium. It is predicted by this principle that the insurance holders are more vulnerable, so 
that they are tend to visit physical doctor more frequently than non-insurance holders. The second type of riskpreference is theory of cherry picker. Chery picker chooses the best cherry to sell to market for fruit. The worse cherry is made for juice. According to the theory of cherry picking, the economic agents who risk averter tend to buy health insurance to cover they health risk. The economic agents who have better health condition prepare for her health risk they probably encounter. It is predicted by the theory that the insurance holder tend to visit doctor less frequent than that uninsured agents (Brownea and Richterb, 2014; Pardo et.al, 2012; Amy and Gary., 2006; Pardo and Schott, 2012; Jingwei, 2017). The end result is uncertain. If lemon effect is higher than of cherry effect, the higher the number of insurance member, the more inefficient the insurance policy is. The higher the cherry effect than of the lemon effect, the more efficient the insurance policy is.

The third issue which is frequently discussed in the health insurance is moral hazard. According to Mendoza (2010), moral hazard is the change in economic behavior, because the economic agents are protected and insured, and the premium is paid by other parties. The economic agents who are already insured, they tend to be less careful than that the uninsured agents. (Wang et.al., 2008; Daval and Kaestner, 2009; Zhiqiang, 2013; Eisenhouer, 2006; Seog, 2012). Mendoza (2010) also reported that moral hazard also happen to the health care providers. Since it is guaranteed that the medical cost are covered by health insurance, so the health care provider tend to offer unnecessary medical treatment. Accordingly, it is predicted the insured agents tend to visit doctor more frequently. The health insurance is inefficient, because of moral hazard.

\section{METHODOLOGY}

There are 1010 people are taken as sample for the study. Among them, 893 people are BPJS health insurance holder, and the rest 117 people are not covered by BPJS yet. The sample are taken from Special Region of Yogyakarta Province. The sample taken by convenience method. All everybody conveniently met are taken as sample. Tool of analysis is Cross Tabulation and Chi Square Test. Using cross tabulation could be investigated the trend of the movement of each groups investigated. The Cross Tabulation could be represented as bellow in Table 1. (Lind et.al., 2015, p 544-545).

If there is no differences in frequencies of visiting medical doctor between member and non-member BPJS, then a11 $\approx \mathrm{a} 12$, a $21 \approx \mathrm{a} 22$, and $\mathrm{a} 31$

a32. If there is a trend that member of BPJS tend to visit medical doctor frequently than that of non-member BPJS, then a31 > a32, and a11< a12.

Statistical test to be employed is Chi Squares (Gujarati and Porter, 2009, p 131). Chi Squares test compare between actual and expected distribution of the observation. The Chi Squared formula could be written as bellow.

$$
2=\sum_{-1-0}={ }_{-1}^{2}
$$

Chi squares statistic is represented by $\chi^{2}, \mathrm{ft}$ is actual distribution, fo is expected distribution. If there is no different between actual and expected distribution, Chi squares statistics tends to be low.

If there is no trend, the expected will be close to the actual distribution. If there is no trend the calculated Chi will be close to zero. If there is a trend, statistically the expected distribution will be different from the the actual distribution of observation.

\section{Table 1. Frequencies of Visiting Medical Doctors according to Categorical Member of BPJS}

\begin{tabular}{|c|c|c|}
\hline & \multicolumn{2}{|c|}{$\%$ Categorical of Sample } \\
\hline $\begin{array}{l}\text { Frequency of } \\
\text { Visiting Medical } \\
\text { Doctors in the } \\
\text { Recent Years }\end{array}$ & $\begin{array}{c}\text { Member of } \\
\text { BPJS }\end{array}$ & Non-Member of BPJS \\
\hline Never & a11 & a12 \\
\hline Once & a21 & a22 \\
\hline More than Once & a31 & a32 \\
\hline
\end{tabular}

Author's Result

\section{IV. RESEARCH RESULT}

There are three hypothesis that need to be statistically tested. First it is investigated the differences in the frequency of accessing the medical doctors by those who are being member of BPJS and non-member of BPJS.

As it is expected by theory, since there are effect lemon and effect cherry picking, the result is uncertain. If effect lemon is higher than cherry picking, they are who have been member of health insurance tend to visit medical doctor more frequently. If cherry picking effect is higher than that of lemon effect, they are who have been member of health insurance tend to visit medical doctor less frequently.

The result as shown in table 2, reveals that members of BPJS more frequently visit medical doctor than that of nonBPJS members. The above table shows that among nonmembers of BPJS there are $89.7 \%$ of them never visit medical doctors. Among the members of BPJS there are only $28.3 \%$ that never visit medical doctors. Among the members of BPJS there are $40.5 \%$ who visit medical doctors once. Among the non-members of BPJS there are only $7.7 \%$ who visit medical doctor once. Among members of BPJS there are $31.7 \%$ who visit medical doctors more than once. Since among non-members of BPJS there are only $2.6 \%$ who visit medical doctors more than once. It could be concluded that there is a trend that member of BPJS tend to visit medical doctor more frequently than of non-member of BPJS.

The trend is statistically tested using Chi Squares test. Using formula on equation (1), Chi statistics is calculated. The calculation results of Chi Statistics is 54.27. Compared to the Chi tables with degree of freedom of 5 and $\alpha=0.01$, which is equal 15 , the Chi statistics is far greater. So it is concluded that the trend is statistically significant. There is a 
trend that the member of BPJS is more frequently to visit medical doctor than non-member of BPJS.

There are two explanation with the trend. Firstly is that probably there is adverse selection. They are who is being member BPJS are they are who is more vulnerable with illness, so they tend to visit medical doctor more frequently than that of non-member of BPJS. The second explanation is that there is moral hazard. Member and non-member health insurance of BPJS they are from the same population. They have the same degree of health. As soon as they are being members of health insurance of BPJS, they change their behavior and visit medical doctor more frequently than nonmember of BPJS.

Those conclusion is in contrast with Hoffman and Browne (2013) finding that cherry picking effect is higher than lemon effect in their study on health insurance in Germany. Those conclusion is in accordance with the finding of Pardo and Schott (2012), Jingwei (2017) in their study of health insurance consecutively in Chillie and Hongkong.
Secondly it is investigated the differences in the frequency of accessing the medical doctors by member of BPJS between those premium is paid by themselves. Other parties in this case oar government and private companies.

The result shows that among member of BPJS whose premium is paid by them-selves, there are $20.8 \%$ who never visit medical doctors in the recent year. Since among member of BPJS whose premium is paid by other parties there are $32.8 \%$ of them who never visit medical doctors in the recent year Among members of BPJS whose premium is paid by them-selves, there are $46.6 \%$ of them who visit medical doctors once in the recent years. Among members of BPJS whose premium is paid by other parties, there are only $36.8 \%$ of them who visit medical doctors once in the recent years. Among members of BPJS whose premium is paid by them-selves, there are $32.6 \%$ of them who visit medical doctor more than once in the recent year. Since only there are $30.4 \%$ of them, who visit medical doctors more than once among BPJS members whose premium is paid

Table 2 : Percentage Frequency of Visiting Medical Doctors Between Members and Non-Members BPJS, 2017

\begin{tabular}{|l|c|c|}
\hline & \multicolumn{2}{|c|}{$\%$ Categorical of Sample } \\
\hline $\begin{array}{l}\text { Frequency of Visiting Medical } \\
\text { Doctors } \\
\text { in the Recent Years }\end{array}$ & $\begin{array}{c}\text { Member of } \\
\text { BPJS }\end{array}$ & Non-Member of BPJS \\
\hline Never & 28.3 & 89.7 \\
\hline Once & 40.5 & 7.7 \\
\hline More than Once & 31.7 & 2.6 \\
\hline Chi Statistic $=54.26915^{*}$ & \multicolumn{2}{|}{} \\
\hline
\end{tabular}

Sources : Research Result ; ${ }^{*}$ significant in $\alpha=$ 0.01

doctors more than once among BPJS members whose premium is paid by other parties. It is statistically significant, that among BPJS members that they are whose premium is paid by them-selves tend to visit medical doctors more frequently than whose premium is paid by other parties.

Those trend is statistically not significant in $\alpha=0.05$ with degree of freedom 5.. The Chi statistics is 3.915, since the chi table in $\alpha=0.05$ and with degree of freedom 5 is 15 . Chi table is higher than chi calculated. Hypothesis that they are who pay the premium of health insurance by themselves rather than paid by other parties tend to go to visit medical doctor more frequently is not accepted. It could be concluded that both categories statistically visit medical doctors equally.

Slightly different result found out by Olayiwola and Kazeem (2019). Their research in Nigeria uncovered that in the case of public health insurance, the higher the income, the more frequent they visit medical doctors. In this research, they are who are and not subsidized visit medical doctor equally.

Finally, it is investigated the differences in the frequency of accessing the medical doctors by all health insurance BPJS members between those premium is subsidized and non-subsidized by government. The subsidy is designed to provide social insurance program toward international health care coverage. If the program is well executed, the economic agents who get subsidy tend to visit medical doctors more frequently.

The table shows that subsidized members tend to visit medical doctors more frequently than that of non-subsidized members. There are $43.6 \%$ of that subsidized, and only $36.4 \%$ that of non-subsidized by Indonesian government visit medical doctor once during one year period. There are $38.5 \%$ of that subsidized, and only $27 \%$ of that nonsubsidized visit medical doctors more than once during one year.

The table shows that subsidized members tend to visit medical doctors more frequently than that of non-subsidized members. There are $43.6 \%$ of that subsidized, and only $36.4 \%$ that of non-subsidized by Indonesian government visit medical doctor once during one year period. There are $38.5 \%$ of that subsidized, and only $27 \%$ of that nonsubsidized visit medical doctors more than once during one year.

\section{CONCLUSION}

It is confirmed that moral hazard is happened in the BPJS case in Indonesia. The moral hazard is triggered by the change in behavior of patients and health service provider. 
The patients who are already member of BPJS tend to visit doctor more easily and frequently. Since the health service providers payments are also insured by the health insurance, they tend to suggest all every medical treatment that probably is not necessarily taken to the patients.

\section{ACKNOLEDGEMENT}

This research is supported by the Directorate General of Higher Education, Ministry of Research, Technology and Higher Education of the Republic of Indonesia, and the Atma Jaya Yogyakarta University, through research scheme International Research Collaboration and Scientific Publication.

Table 3 : Percentage Frequency of Visiting Medical Doctors by Member of BPJS Between Whose Premium is Paid By Them-Selves and Paid by Other Parties 2017

\begin{tabular}{|c|c|c|}
\hline & \multicolumn{2}{|c|}{$\begin{array}{l}\% \text { of Member of BPJS Whose } \\
\text { Premium }\end{array}$} \\
\hline $\begin{array}{l}\text { Doctors in the Recent } \\
\text { Years }\end{array}$ & $\begin{array}{c}\text { Paid By } \\
\text { Them Selves }\end{array}$ & Paid by Other Parties \\
\hline Never & 20.8 & 32.8 \\
\hline Once & 46.6 & 36.8 \\
\hline More than Once & 32.6 & 30.4 \\
\hline Total & 100 & 100 \\
\hline Chi Statistics $=3.915$ & & \\
\hline
\end{tabular}

Sources : Research Result

\section{REFERENCES}

1. A. Finkelstein, and M.G.,Katleen, "Mutliple, Dimension of Private Information, Evidence From Long Term Insurance Market," The American Economic Review, Vol 96, No 4, pp 938- 958, September 2006.

2. B. R. Binger, and E. Hoffman, "Microeconomics With Calculus," Scott, Foresman and Company, London, pp 505 , 1988

3. M. J. Brownea, and R. T. Zhou, "Lemons or Cherries? Asymmetric Information in the German Private Long-term Care Insurance Market," The Geneva Papers, 2014, 39, pp 603-624, 2014.

4. Y. G. Eisenhouer., "Severity of Illness and the Welfare Effects of Moral Hazard," International Journal of Health Care Finance and Economics, Vol. 6, DOI 10.1007/s10754006-9006-3, pp 290-299, 2006.

5. M. Gaynor, K. Ho, and R. J. Town, "The Industrial Organization of Health Care Martket," Journal of Economic Literature, $53 \quad$ (2), pp 235-284, 2015 http//:dx.doi.org/10.1257/JEL, 53.2.235

6. D. N. Gujarati. and D. C. Porter, "Basic Econometrics," $5^{\text {th }}$ Eddition, McGraw-Hill, 2009

7. B. Hackmann, J.T. Martin,, A. E. Kowalski, "Health Reform, Health Insurance, and Selection: Estimating Selection into Health Insurance Using the Massachusetts Health Reform," American Economic Review, Paper and Proceeding, 102 (3), pp 498-501, 2012.

8. A. Hoffman, and M. Browne, "One-sided commitment in Dynamic Insurance Contracts: Evidence from Private Health Insurance in Germany," Journal Risk Uncertain, 46, pp 81112, 22 January 2013.

9. A.H. Jingwei,, "Introducing Voluntary Private Health Insurance in Mixed Medical Economy: Are Hongkong Citizen Willing to Subscribe?," The BMC Health Service Research, 17: 603, pp 1-10, 2017. DOI, 10.1186/s12913-017-2559-
10. D.A. Lind, W. G. Marshal, S. A. Wathen, "Statistical Techniques in Business and Economics," $16^{\text {th }}$ Ed., Mc-Graw Hill, 2015.

11. L. R. Mendoza, "Which Moral Hazard ? Health Care Reform Under The Affordable Care Act of 2010," Journal of Health Organization and Management, Vol 30, No 4, 2016, pp 510529, 2016. @ Emerald Group Publishing Limited 1477-7266: DOI 10.1108/JHOM-03-2015-0054

12. S. O. Olayiwola., and B. L.O. Kazeem, "Count Data Modelling of Health Insurance and Health Care Utilization in Nigeria," Journal of Economics and Management, Vol. 35 (1) pp 106-123, 2019. ISSN 1732-1948

13. C. Pardo, and W. Schott, "Public Versus Private : Evidence On Health Insurance Selection," International Journal of Health Care Finance Economics, 12, pp 39-61, 2012. DOI, 10-1007/s10754-012-9105-2, 2012 (47)

14. H. S. Seog,., "Moral Hazard and Health Insurance When Treatment is Preventive," The Journal of Risk and Insurance, Vol. 79, No. 4, pp 1017-1038, 2012. DOI: 10.1111/j.15396975.2011.01459.x

15. J. L. Wang, C. F. Chung, and L. Y. Tzeng, "An Empirical Analysis of The Effect of Increasing Deductible of Moral Hazard," Journal of Risk and Insurance, Vol 75. No. 3, pp 511-566, 2008.

16. Y. Wang, Y. Linsen, and P. Wenjie, "Life Insurance Contribution, Insurance Development, and Economic Growth in China," International Journal of Business and Economic Development, Vol 5, No 2, pp 45-58, 2017.

17. Y. Zhiqiang, "Testing For Moral Hazard in reinsurance Market”, Managerial Finance, Vol. 39, No.8, 2013. 